\title{
Impact of Tourism Sector on Gross Domestic Product Growth in Jordan
}

\author{
Khaled Abdalla Moh'd AL-Tamimi ${ }^{1}$ \\ ${ }^{1}$ Department of Financial and Administrative Sciences, Irbid University College, Al-Balqa' Applied University, \\ Jordan \\ Correspondence: Khaled Abdalla Moh'd AL-Tamimi, Associate professor, Department of Financial and \\ Administrative Sciences, Irbid University College, Al-Balqa' Applied University, Jordan.
}

Received: August 2, 2019

doi:10.5430/rwe.v11n1p106
Accepted: August 23, 2019

Online Published: March 5, 2020

URL: https://doi.org/10.5430/rwe.v11n1p106

\begin{abstract}
This study investigates the impact of development of tourism sector on GDP growth rate in Jordan by depending on annual statistics for the period (2010 - 2017); as receipts of tourism sector percentage to exports, arrivals of tourists and expenditures of tourism sector percentage to imports are independent variables, while growth rate of GDP (an indicator of economic growth), is a dependent variable. This paper begins with theoretical studies that analyze the impact of development of tourism sector on GDP growth rate, and empirical studies to analyze this impact. After that, it analyzes the impact of development of tourism sector on GDP growth rate in Jordan by depending on annual statistics for the period $(2010$ - 2017) by depending on ordinary least squares method by SPSS version. The study finds insignificant impacts of receipts of tourism sector percentage to exports and arrivals of tourists on GDP growth rate in Jordan by depending on annual statistics for the period 2010 to 2017, but there is a negative and significant impact of expenditures of tourism sector percentage to imports on GDP growth rate in Jordan by depending on annual statistics for the period 2010 to 2017. The study recommends decreasing expenditures of tourism sector due to their negative impacts on GDP growth rate.
\end{abstract}

Keywords: tourism sector, arrivals of tourists, economic growth, GDP growth

\section{Introduction}

Achieving economic development in any country depends on having some solutions for economic obstacles that the country faces, like: budget deficit, deficit of balance of payment, inflation, unemployment, or instability of fiscal and monetrary sectors. This way, the tourism sector is seen as a solution for these problems and obstacles (Kum, Aslan and Gungor, 2015, p. 1075).

The tourism sector has enhanced depending on statistics of World Travel and Tourism Council. As its percentage to world economic growth rose to $9.5 \%$, and the tourism sector created more than 4.7 million jobs in 2013 (Kum, Aslan and Gungor, 2015, p. 1075).

The tourism sector is seen as one of the biggest and fastest developing services sectors in the world, as tourism sector enhances reserves of foreign currency, gives positive externalities, enhances accumulation of capital and makes new activities of investment, so the tourism sector is seen as one of the most important sectors that enhances GDP growth rate (Kum, Aslan and Gungor, 2015, p. 1075).

In this context, this study analyzes the impact of tourism sector on GDP growth rate in Jordan by depending on annual statistics for the period (2010-2017), And that is accomplished by beginning with theoretical studies of tourism sector impact on GDP growth rate, empirical studies that analyze this impact, and explaining the aim of this study of the impact of tourism sector on GDP growth rate in Jordan by depending on annual statistics for the period (2010-2017) by using ordinary least squares method .

\section{Importance of the Study}

- The impact of tourism sector on GDP growth rate can be analyzed by achieving tourists' needs; as tourists want some services, like: sports, accommodation, or transportation in host country. Achieving these needs of tourists leads to positive impacts in a lot of sectors in the society. as follows: 
- Job Sector: by enhancing the production of tourism sector, employment opportunities are created in the tourism sector and other sectors impacted by it. This impact is concerned with developing countries that have a lot of labor and less capital industries.

- Income sector: tourism sector leads to increased profits, revenues and sales, and so, enhances income in the host country. Part of this income is paid for some factors of production, like: rent, salaries and wages. As well as the previous income, investment in tourism sector multiplies income, and that enhances economic growth, and decreases income inequality by striking balance in redistributing the income (Kum, Aslan and Gungor, 2015, p. 1075).

- Fiscal sector tourism sector leads to increased tax revenues in the country, and that results in increasing and improving the investment in infrastructure projects, such as: roads, tunnels, sewage systems, sanitation, schools in rural areas, health enhancing ... etc. In the case of increasing and enhancing public investments, positive externalities will be constructed by enhancing arrivals of tourists in the long term, but these expenditures on infrastructure that arise from arrivals of tourists and their accomodation lead to an increase in financing requirements for infrastructure investments.

- Cultural Sector: the standard of living of population is enhanced; as employing labor force results in improving investments in human capital in fields, such as: healthcare, transportation, education, communication ... etc. Tourism sector also improves the education levels of households.

- Business Sector: tourism sector has a positive effect on economic income; as tourism sector comes with knowledge, technology, research, and human capital to the host country.

- Household Sector: tourism may lead to inflation, as in: the times of arrival and accommodation of tourists in the host country, and increase of prices of goods and services. That leads to inflation and inflow of currency by tourists in the host country. It may have an effect on the quantity and quality of services and goods in the country (Kum, Aslan and Gungor, 2015, pp. 1075 - 1076).

From the above impacts, the net impact of tourism sector on GDP growth rate is positive despite costs that may arise from the arrival and accommodation of tourists in the host country (Kum, Aslan and Gungor, 2015, p. 1076).

\section{Literature Review}

Many papers exist which anlayzes the impact of tourism sector on GDP growth rate as follows:

1- Kum, Aslan and Gungor's paper analyzes the impact of tourism sector on GDP growth rate in the next 11 countries by depending on annual statistics for the period 1995 to 2013 by using panel cointegration models. This study found a relationship between arrivals of tourists and GDP growth rate in the next 11 countries and a positive impact of tourists' arrivals on GDP growth rate during the period of this study.

2- Yilmaz's study analyzes the impact of tourism sector on GDP growth rate in some states by using Quarterly data during the period (first quarter of 2004 - second quarter of 2013) by depending on estimation of ordinary least squares. This paper found an indirect impact of the tourism sector on GDP growth rate; because there are a lot of factors that have effects on this impact.

3- Akan, Arslan and Isk's study analyzes the effect of tourism sector on GDP growth rate in Turkey by depending on annual statistics for the period 1985 to 2007 through Johanson Cointegration estimation, a Vector Autoregression model and Granger Causality test. The study results show that tourism sector has an increasing effect on GDP growth rate in the long term, and a causality between tourism sector and GDP growth rate.

4- Tabash's study analyzes the impact of the receipts of tourism sector on GDP growth rate for Palestine by depending on annual statistics for the period (1995 - 2014) by using Johanson Cointegration estimation. It found a unique positive impact of the receipts of tourism sector on GDP growth rate in the long run.

5- Alhowaish's study analyzes the impact of enhancing tourism sector on GDP growth rate for states of Gulf Cooperation Council (GCC) by using Panel data method, by depending on annual statistics for the period 1995 to 2012. This paper found a one way causality from GDP growth rate to the development of tourism sector in countries of Gulf Cooperation Council (GCC).

6- Ekanayake and Long's paper studies the impact of the development of tourism sector on GDP growth rate in a set of 140 developing contries by depending on annual statistics for the period 1995 to 2009 using Granger 
causality test. This paper found a positive and significant impact from the development of tourism sector to GDP growth rate in developing countries.

7- Govdeli and Direkci's study analyzes the impact of tourism revenues on GDP growth rate in 34 OECD countries by depending on annual statistics for the period 1997 to 2012 by using a panel cointegration test, and the study found that the revenues of tourism sector have increasing impacts on GDP growth rate in the long term.

8- Samimi, Somaye Sadeghi and Soraya Sadeghi's study studies the impact of enhancing tourism sector on GDP growth rate in developing countries by depending on annual statistics for the period 1995 to 2009 by using P- VAR. The study found an increasing impact of developing tourism sector on GDP growth rate in developing countries.

9- Fayissa, Nsiah, and Tadasse's study concentrates on studying the effect of development of tourism industry on GDP growth rate in a sample of 42 African countries by depending on annual statistics for the period 1995 to 2004 by using Cointegration test. This paper found a positive and significant impact of the receipts from the tourism industry on the GDP growth rate for African countries.

Most of these papers find positive and significant impacts of the development of tourism sector on GDP growth rate, which shows that all these states depend on the tourism sector for helping to grow the macroeconomy. These previous studies lack analyzing the effect of different indicators of tourism sector on economic growth, but this study takes into consideration this point as it analyzes the effects of arrivals of tourists, receipts of tourism sector percentage to exports and expenditures of tourism sector percentage to imports on economic growth in Jordan, and that is what this study is going to contribute in this area of research. The geographical limitation of the study is Jordan and the time limitation of the study is annual data for the period (2010-2017).

\section{Impact of the Development of Tourism Sector on GDP Growth Rate in Jordan According to the Annual Statistics for Period 2010 to 2017}

\subsection{Method}

This paper depends on annual statistics for the period (2010-2017) for tourism sector arrivals, receipts of tourism sector percentage to exports, expenditures of tourism sector percentage to imports and GDP growth rate variables for Jordan. The next equation shows the impact of the development of tourism sector on GDP growth rate:

$$
\begin{aligned}
& \text { Economic growth }{ }_{t} \\
& =\alpha_{0}+\alpha_{1} \text { arrivals of tourists } s_{t} \\
& +\alpha_{2} \text { receipts of tourism sector percentage to exports } t_{t} \\
& +\alpha_{3} \text { expenditures of tourism sector percentage to imports } s_{t}+\varepsilon_{t}
\end{aligned}
$$

\subsection{Results}

This section concentrates on tourism sector arrivals, receipts of tourism sector percentage to exports, expenditures of tourism sector percentage to imports, and GDP growth rate variables in Jordan by depending on annual statistics for the period 2010 to 2017 as follows:

\subsubsection{Arrivals of Tourists in Jordan}

Table 1. Arrivals of tourists in Jordan by depending on annual statistics for the period 2010 to 2017

\begin{tabular}{lc}
\hline Year & Arrivals of tourists \\
\hline 2010 & 4207000 \\
2011 & 3960000 \\
2012 & 4162000 \\
2013 & 3945000 \\
2014 & 3990000 \\
2015 & 3761000 \\
2016 & 3567000 \\
2017 & 3843500 \\
\hline
\end{tabular}

Source Researcher conducting depending on World Bank data 


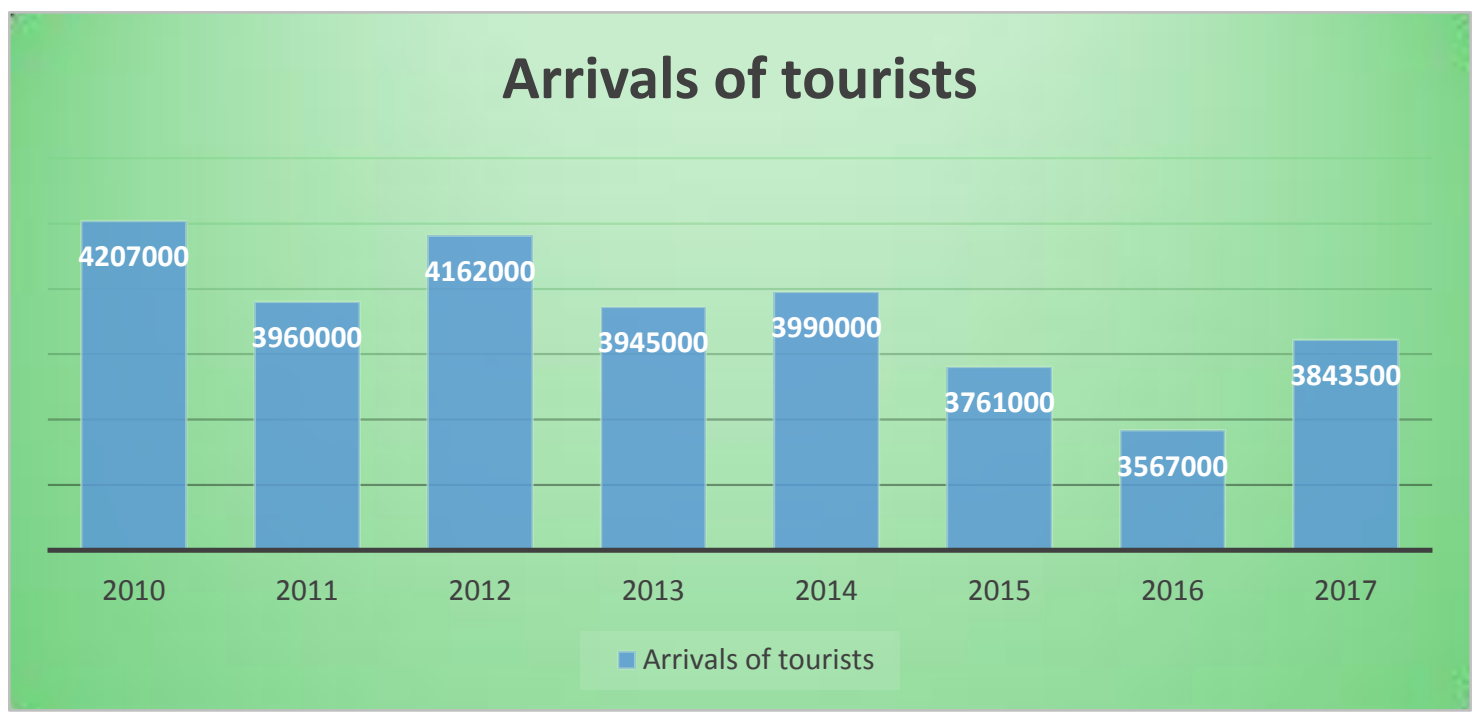

Figure 1. Arrivals of tourists in Jordan by depending on annual statistics for the period 2010 to 2017 Source: Researcher conducting depending on World Bank data

The table and figure above show that there is a fluctuation in the arrivals of tourists for Jordan by depending on annual statistics for the period 2010 to 2017. They indicate that the arrivals of tourists decrease from 4207000 tourists in 2010 to 3960000 tourists in 2011, then they increase to 4162000 tourists in 2012 and decrease in 2013, increase in 2014 then decrease in 2015 and 2016 and increase to 3943500 in 2017.

\subsubsection{Receipts of Tourism Sector Percentage to Exports in Jordan}

Table 2. Receipts of tourism sector percentage to exports in Jordan (\%) by depending on annual statistics for the period 2010 to 2017

\begin{tabular}{cc}
\hline Year & $\begin{array}{c}\text { Receipts of tourism sector percentage to } \\
\text { exports }\end{array}$ \\
\hline 2010 & 34.4 \\
2011 & 31.7 \\
2012 & 35.8 \\
2013 & 36.2 \\
2014 & 35.5 \\
2015 & 35.2 \\
2016 & 36.4 \\
2017 & 38.8 \\
\hline
\end{tabular}

Source: Researcher conducting depending on World Bank data 


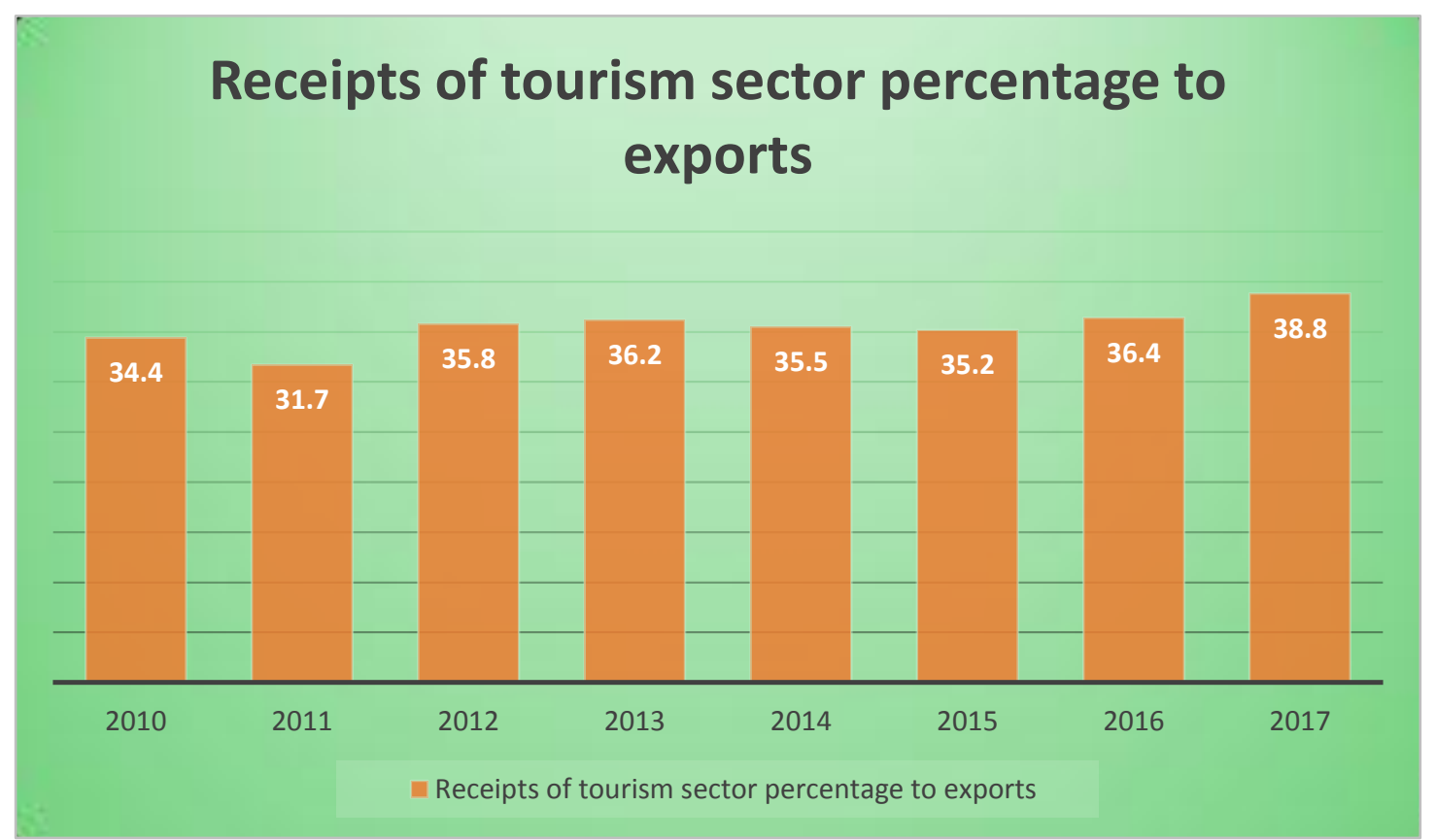

Figure 2. Receipts of tourism sector percentage to exports in Jordan (\%)by depending on annual statistics for the period 2010 to 2017

Source: Researcher conducting depending on World Bank data

The table and figure above show that there is a fluctuation in the receipts of tourism sector percentage to exports for Jordan by depending on annual statistics for the period 2010 to 2017. They indicate that the receipts of tourism sector percentage to exports decreases from $34.4 \%$ in 2010 to $31.7 \%$ in 2011 then it increases to $35.8 \%$ and $36.2 \%$ in 2012 and 2013 respectively.They decrease in 2014 and 2015, then increase in 2016 and 2017 to be $36.4 \%$ and $38.8 \%$ respectively.

\subsubsection{Expenditures of Tourism Sector Percentage to Imports in Jordan}

Table 3. Expenditures of tourism sector percentage to imports in Jordan (\%)by depending on annual statistics for the period 2010 to 2017

\begin{tabular}{cc}
\hline Year & $\begin{array}{c}\text { Expenditures of tourism sector } \\
\text { percentage to imports }\end{array}$ \\
\hline 2010 & 9.5 \\
2011 & 6 \\
2012 & 5.5 \\
2013 & 5 \\
2014 & 5.1 \\
2015 & 5.6 \\
2016 & 6.3 \\
2017 & 6.5 \\
\hline
\end{tabular}

Source: Researcher conducting depending on World Bank data 


\section{Expenditures of tourism sector percentage to imports}

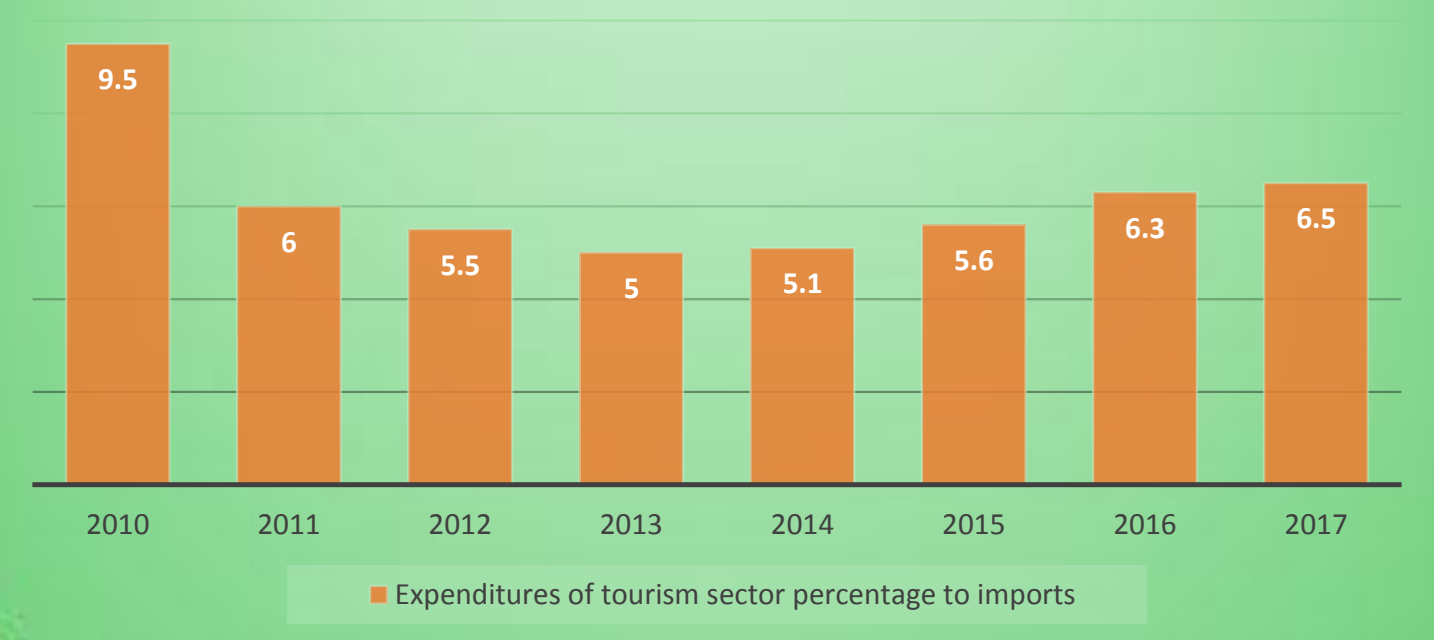

Figure 3. Expenditures of tourism sector percentage to imports in Jordan by depending on annual statistics for the period 2010 to 2017

Source: Researcher conducting depending on World Bank data

The table and figure above show that there is a fluctuation in the expenditures of tourism sector percentage to imports for Jordan by depending on annual statistics for the period 2010 to 2017. They indicate that the expenditures of tourism sector percentage to imports decrease from $9.5 \%$ in 2010 to $5 \%$ in 2013 then it increase to $6.5 \%$ in 2017.

4.2.4 GDP Growth Rate (As a Proxy of Economic Growth) for Jordan

Table 4. GDP Growth rate in Jordan (\%) by depending on annual statistics for the period 2010 to 2017

\begin{tabular}{cc}
\hline Year & GDP growth rate \\
\hline 2010 & 0.004 \\
2011 & 2.5 \\
2012 & 2.3 \\
2013 & 3.1 \\
2014 & 3 \\
2015 & 2.4 \\
2016 & 2.3 \\
2017 & 2.2 \\
\hline
\end{tabular}

Source: Researcher conducting depending on World Bank data 


\section{GDP Growth rate}

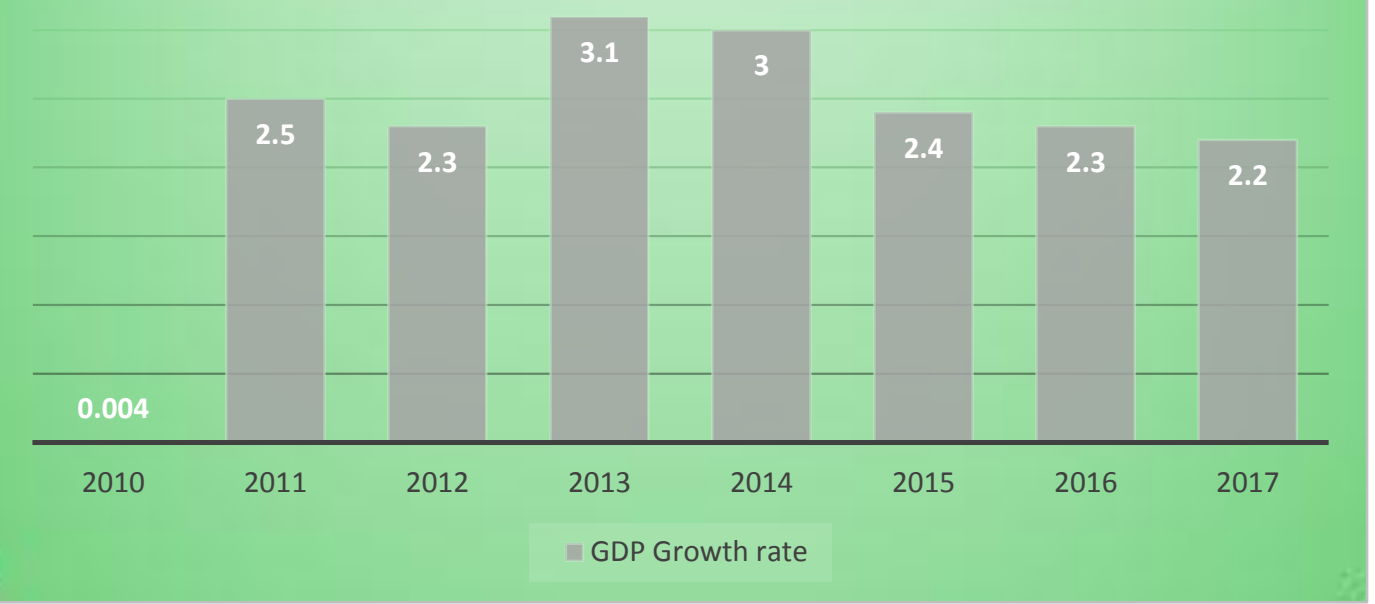

Figure 4. GDP Growth rate in Jordan by depending on annual statistics for the period 2010 to 2017 Source: Researcher conducting depending on World Bank data

Table and Figure 4 indicate to growth rate of GDP in Jordan by depending on annual statistics for the period 2010 to 2017. They show that growth rate of GDP raises for the first part of period $0.004 \%$ in 2010 to $3.1 \%$ in 2013 , however it decreases through the second part of this period to $2.2 \%$ in 2017 .

\section{Discussion}

The following figure represents the impact of the development of tourism sector on GDP growth rate in Jordan by depending on annual statistics for the period 2010 to 2017 as follows:

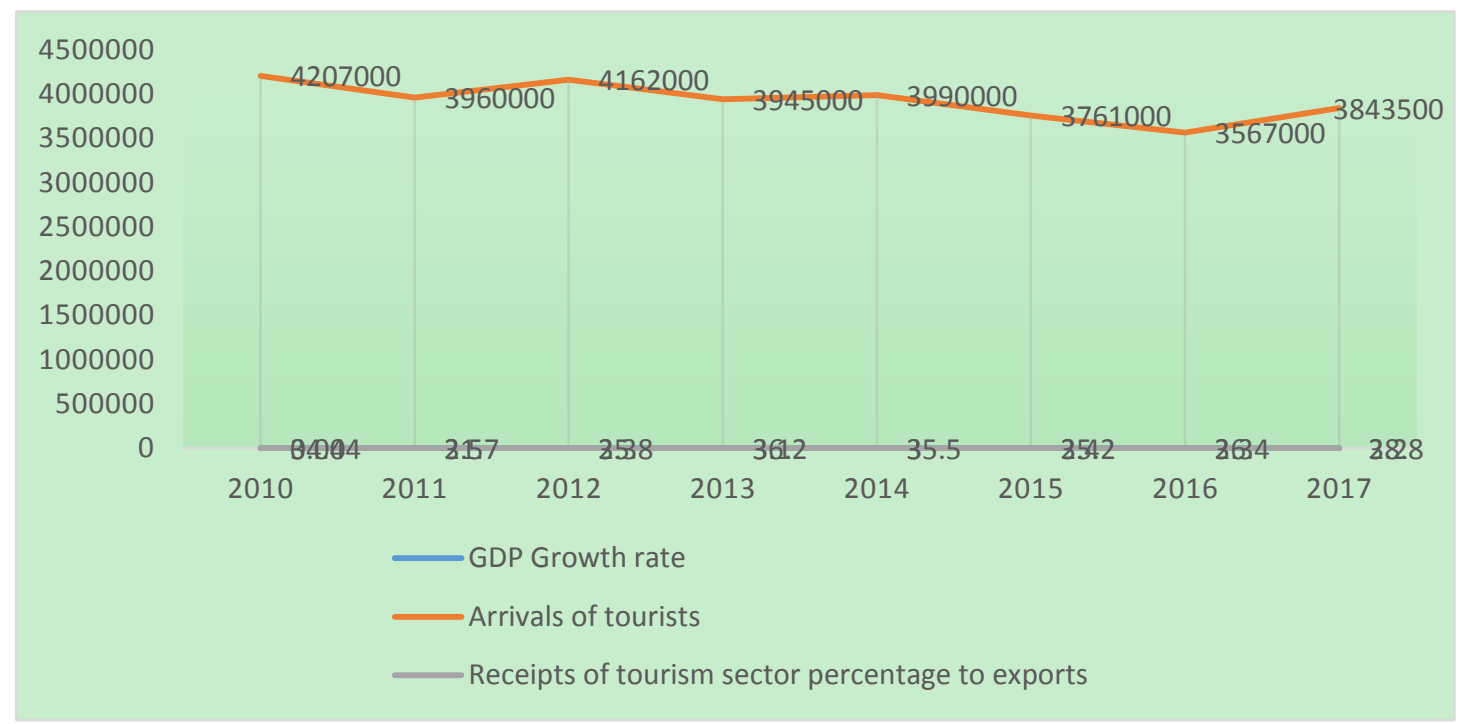

Figure 5. Receipts of tourism sector percentage to exports, Arrivals of tourists and GDP Growth rate in Jordan by depending on annual statistics for the period 2010 to 2017

Source: Researcher conducting depending on World Bank data 
Figure 5 shows the impact of the development of tourism sector on GDP growth rate in Jordan by depending on annual statistics for the period 2010 to 2017. The figure above shows a positive impact of the development of tourism sector on economic growth in Jordan; as when the development of the tourism sector increases, GDP growth rate increases, and vice versa.

To prove this relationship, the researcher depends on the ordinary least squares method to analyze the impact of the development of tourism sector on GDP growth rate in Jordan by depending on annual statistics for the period 2010 to 2017, as follows:

Dependent Variable: GROWTH

Method: Least Squares

Sample: 20102017

Included observations: 8

\begin{tabular}{llllc}
\hline \hline Prob. & t-Statistic & Std. Error & Coefficient & Variable \\
\hline \hline 0.9146 & -0.114116 & 0.046132 & -0.005264 & REC \\
0.3491 & -1.059570 & $4.66 \mathrm{E}-07$ & $-4.94 \mathrm{E}-07$ & ARRI \\
0.0006 & -9.701631 & 0.064645 & -0.627162 & EX \\
0.0396 & 3.007830 & 2.737894 & 8.235120 & $\mathrm{C}$ \\
\hline \hline
\end{tabular}

\begin{tabular}{lrr}
\hline \hline & Mean dependent & \\
2.225500 & variable 0.966410 & R-squared \\
0.957468 & S.D. dependent variable 0.941217 & Adjusted R-squared \\
0.223893 & Akaike info criterion 0.232139 & S.E. of regression \\
0.263614 & Schwarz criterion 0.215554 & Sum squared residuals \\
-0.044007 & Hannan-Quinn criteria. 3.104427 & Log likelihood \\
2.692180 & Durbin-Watson stat 38.36100 & F-statistic \\
& 0.002092 & Probability \\
& & (F-statistic)
\end{tabular}

The above table shows that there are insignificant impacts of receipts of tourism sector percentage to exports and arrivals of tourists on GDP Growth rate in Jordan by depending on annual statistics for the period 2010 to 2017 at significance level 5\%, but there is a negative and significant impact of expenditures of tourism sector percentage to imports on GDP growth rate in Jordan by depending on annual statistics for the period 2010 to 2017 at a significance level $5 \%$.

\section{Conclusion and Recommendations}

This paper explains the impact of the development of tourism sector on GDP growth rate in both theoretical and empirical studies, this impact on Jordan by depending on annual statistics for the period 2010 to 2017. This paper finds insignificant impacts of receipts of tourism sector percentage to exports and arrivals of tourists on GDP Growth rate for Jordan by depending on annual statistics for the period 2010 to 2017, but there are negative and significant impacts of expenditures of tourism sector percentage to imports on GDP growth rate in Jordan by depending on annual statistics for the period 2010 to 2017.

The study recommends decreasing expenditures of tourism sector due to its negative impact on GDP growth rate.

\section{References}

Akan, Y., Arslan, A., \& Isk, C. (2007). The Impact of Tourism on Economic Growth: The Case of Turkey. Journal of Tourism, IX. Retrieved from https://docplayer.net/52122367-The-impact-of-tourism-on-economic-growth-the-case-of-turkey-yusuf-akan-dep artment-of-economics-ataturk-university-erzurum-turkey.html 
Alhowaish, A. (2016). Is Tourism Development a Sustainable Economic Growth Strategy in the Long Run? Evidence from GCC Countries. Sustainability, 8(605). Retrieved from https://res.mdpi.com/sustainability/sustainability-08-00605/article_deploy/sustainability-08-00605.pdf?filename $=\&$ attachment $=1$

Ekanayake, E. M., \& Long, A. (2012). Tourism Development and Economic Growth in Developing Countries. The International Journal of Business and Finance Research, 6(1). Retrieved from file:///C:/Users/user/Downloads/IJBFR-V6N1-2012-5.pdf

Fayissa, B., Nsiah, C., \& Tadasse, B. (2007). The Impact of Tourism on Economic Growth and Development in Africa. Department of Economics and Finance Working Paper Series. Retrieved from http://capone.mtsu.edu/berc/working/TourismAfricawp.pdf

Govdeli, T., \& Direkci, T. (2017). The Relationship between Tourism and Economic Growth: OECD Countries. International Journal of Academic Research in Economics and Management Sciences, 6(4). Retrieved from http://hrmars.com/hrmars_papers/The_Relationship_between_Tourism_and_Economic_Growth_OECD_Countr ies1.pdf

Kum, H., Aslan, A., \& Gungor, M. (2015). Tourism and Economic Growth: The Case of Next-11 Countries. International Journal of Economics and Financial Issues, 5(4), 1075-1081. Retrieved from https://dergipark.org.tr/download/article-file/363129

Samimi, A., SomayeSadeghi, \& SorayaSadeghi. (2011). Tourism and Economic Growth in Developing Countries: P-VAR Approach. Middle-East Journal of Scientific Research, 10(1), 28-32. Retrieved from https://pdfs.semanticscholar.org/2737/b30231cbbf9fb9157ef477d47e5e975ff0f6.pdf

Tabash, M. (2017). The Role of Tourism Sector in Economic Growth: An Empirical Evidence from Palestine. International Journal of Economics and Financial Issues, 7(2), 103-108. https://www.econjournals.com/index.php/ijefi/article/viewFile/3893/pdf

World Bank data. Retrieved from https://data.worldbank.org/

Yilmaz, A. (2014). Impact of Tourism Industry on Economic Growth. DokuzEylul University, Faculty of Business. Retrieved from http://www.ijbts-journal.com/images/column_1432348023/full\%20paper\%20paris1.pdf 